\title{
Pediatric oncology nursing workers: the use of defensive strategies at work
}

Trabalhadores de enfermagem em oncologia pediátrica: o uso de estratégias defensivas no trabalho Trabajadores de enfermería oncológica pediátrica: el uso de estrategias defensivas en el trabajo

\author{
Viviani Viero \\ Carmem Lúcia Colomé Beck ${ }^{1}$ \\ Alexa Pupiara Flores Coelho ${ }^{1}$ \\ Daiane Dal Pai \\ Paula Hübner Freitas ${ }^{1}$
}

Marcelo Nunes da Silva Fernandes ${ }^{3}$

1. Universidade Federal de Santa Maria.

Santa Maria, RS, Brasil.

2. Universidade Federal do Rio Grande do Sul. Porto Alegre, RS, Brasil.

3. Prefeitura Municipal de Santa Maria.

Santa Maria, RS, Brasil.

\section{Corresponding author:}

Viviani Viero.

E-mail: viviviero@hotmail.com

Submitted on $03 / 27 / 2017$.

Accepted on 06/26/2017.

DOI: 10.1590/2177-9465-EAN-2017-0058

\section{Abstract}

Objective: To describe defensive strategies used by nursing workers in pediatric oncology towards suffering at work. Methodology: A qualitative, exploratory and descriptive study was carried out in 2013 with 20 nursing workers of pediatric oncology at a teaching hospital. The techniques of non-participant observation and focus group were used to produce the data, which were submitted to thematic analysis. Results: Some of the individual strategies identified were conformity, distancing from the experience with children, rationalization, and refuge in pleasurable moments. Furthermore, group strategies were pointed out, such as speaking and listening, coming together as a work group, redefining suffering, and the search for a new meaning in life. Conclusions: Spaces for speaking and listening can enable the sharing of experiences of suffering, helping workers to recognize defensive strategies and strengthen resistance actions.

Keywords: Nursing; Occupational health; Medical oncology; Pediatrics; Qualitative research.

\section{Resumo}

Objetivo: Descrever as estratégias defensivas utilizadas por trabalhadores de enfermagem em oncologia pediátrica frente ao sofrimento no trabalho. Metodologia: Estudo qualitativo, exploratório-descritivo, realizado, em 2013, com 20 trabalhadores de enfermagem atuantes em oncologia pediátrica de um hospital universitário. Para a produção de dados foi empregada a técnica da observação não participante e do Grupo Focal. Os dados foram submetidos à análise temática de conteúdo. Resultados: Algumas estratégias individuais identificadas foram conformismo, distanciamento do convívio com as crianças, racionalização e refúgio nos momentos de lazer. Além disso, foram apontadas estratégias coletivas como os movimentos de fala e escuta, a agregação do coletivo de trabalho, a ressignificação do sofrimento e a busca de um novo sentido para a vida. Conclusões: Espaços de fala e escuta podem possibilitar a partilha das vivências de sofrimento, auxiliando o trabalhador a reconhecer as estratégias defensivas e fortalecer os movimentos de resistência.

Palavras-chave: Enfermagem; Saúde do trabalhador; Oncologia; Pediatria; Pesquisa qualitativa

\section{Resumen}

Objetivo: Describir las estrategias defensivas utilizadas por trabajadores de enfermería en oncología pediátrica delante el sufrimiento en el trabajo. Metodología: Estudio cualitativo, exploratorio y descriptivo, realizado en 2013 con 20 trabajadores de enfermería actuantes en oncología pediátrica de un hospital universitario. Para la producción de datos fue empleada la técnica de observación non-participante y grupo focal. Los datos fueron sometidos al análisis temático de contenido. Resultados: Algunas estrategias individuales identificadas fueron conformismo, distanciamiento del convivio con niños, racionalización y refugio en momentos de ocio. Además, fueron apuntadas estrategias colectivas como los movimientos de hablar y escuchar, la agregación del colectivo de trabajo, resignificación de sufrimiento y búsqueda de un nuevo sentido para la vida. Conclusiones: Espacios de habla y escucha pueden posibilitar el compartir las vivencias de sufrimiento, ayudando al trabajador a reconocer las estrategias defensivas y fortalecer los movimientos de resistencia.

Palabras clave: Enfermería; Salud laboral; Oncología médica; Pediatría; Investigación cualitativa. 


\section{INTRODUCTION}

Nursing care for children with cancer is a complex activity. It involves a number of feelings influenced by aspects such as the impossibility of cure, frustration with the perspective of life expected for a child and expectation of death of a fragile being who is protected by their family and society. ${ }^{1}$ In this sense, the routine follow-up of the pain of children and family members who experience disease and death at an early age can be a stressful experience for nursing workers. ${ }^{2}$

The nursing team can encounter difficulties in their pediatric oncology work routine due to the contact with pain, suffering and death of sick children. Professionals experience different feelings as a result of work experiences, which range from grieving to escape from and denial of suffering. ${ }^{3}$ This shows the development of defensive and coping strategies, both individual and group ones, which are specific according to the work organization where professionals are included and aim to alleviate suffering. ${ }^{4}$

Defensive strategies function as "escape routes", which workers may or may not be aware of and take advantage of in adverse situations and experiences of suffering in the workplace. They are frequently necessary for these workers to adapt to such situations by changing their own perception of reality, allowing it to become acceptable. The use of defensive strategies is a mental operation that leads to modification, transformation or euphemization of workers' perception of the reality that causes them to suffer. ${ }^{5}$

Individual defense strategies are internalized in the personal experience of individuals with their work, whereas group strategies are constructed and strengthened by the group of workers, being common to all. Defensive strategies are constructed by the work group so that these workers can resist to the suffering, frustrations and contradictions existing between workers' desires and the hard work reality. ${ }^{4,5}$

More in-depth studies in the area of workers' health can help one to understand the causal relationship between the labor context and the positive and negative impacts on the health of those who have worked. In view of this situation, studies that analyze nursing work are relevant, as this often includes adverse conditions that can have negative repercussions for the health of these individuals. ${ }^{6}$

A recent review on the international literature showed that health workers are not prepared to deal with difficult situations in pediatric oncology, especially child death and family mourning. ${ }^{7}$ Additionally, the demands from parents, children and work organization contribute to nursing workers' experiencing intense feelings that can lead to suffering. ${ }^{8}$ Thus, to understand the losses that such workers experienced is important to establish effective educational and support strategies. ${ }^{9}$

In this sense, the present study aims to describe defensive strategies used by nursing workers in pediatric oncology when dealing with suffering in the workplace.

\section{METHODS}

An exploratory descriptive study with a qualitative approach was performed, discussed in the light of Work Psychodynamics, a line of thinking developed by French psychiatrist Christophe Dejours, who study the relationships between work and mental health. ${ }^{4,5}$ The study setting was a University Hospital situated in the countryside of Rio Grande do Sul state, Brazil, whose oncology-hematology ward is a model health service for the central region of the state. This study was performed in two sectors aimed at pediatric oncology care: a hospitalization unit and an outpatient service unit.

Research participants were 20 nursing workers (nurses and nursing technicians and assistants) who met the inclusion criteria: to be an active nursing worker in the institution, in pediatric oncology care. Individuals who were on a leave from work for any reason during data production were excluded from this study. It should be emphasized that all nursing workers from both sectors (totaling 32 workers), who were approached in their work shifts after individual printed invitations were sent to them and a poster was put up on notice boards in the wards. The group included those willing to voluntarily participate in the study.

Data collection/production was performed from February to May 2013, using non-participant observation techniques and Focus Groups (FG). ${ }^{10}$ Observations occurred in the morning, afternoon and evening shifts, totaling 30 hours in the hospitalization ward and 30 hours in the morning and afternoon shifts in the outpatient clinic, as it did not provide services in the evenings. Thus, there was a total of 60 hours of observation, distributed in periods of six hours, on average.

The observations were made by the researcher herself, who was also a professional in one of the services. It was aimed at the nursing work routine in the units, as the relationships of nursing care for children and their family members and the dynamics and interactions between workers themselves occurred. Data were compiled in a field journal and used to complement the FG.

In all, four FG sessions lasting two hours each were performed in rooms situated in the institution itself, guaranteeing participants' privacy, comfort and anonymity. The two first sessions included the participation of nine workers in each session; in the third one, there were five workers; and in the fourth one, seven workers.

In the first session, all possible ethical questions were answered and the socio-work questionnaire developed by the researcher herself, including questions such as age, sex, number of children, profession, level of education, length of time in the profession and in the oncology area, work shift and employment relationship.

Sessions were guided by questions aimed at the study objective, such as: What is it like to work in pediatric oncology? What led you to work with pediatric oncology? What were your first impressions when you arrived here? How do you feel in this job? What makes you feel well or not in this job? How do you deal with something that does not make you feel good? 
Furthermore, adequate group techniques were applied to achieve the objectives, such as dynamics for warm-up and self-knowledge and those promoting discussion. Sessions were conducted by a moderator, who was the main researcher, and three research assistants, who had been instructed about the methodology and helped in other studies with Focus Groups.

It is important to emphasize that outpatient services were set up in a way that workers had some available time to participate in data production, without service users being affected. In contrast, hospitalization unit workers were given the opportunity to get together in the workplace, at a time when the demand for services was low in the unit.

The speech of workers coming from the FG and the observation records were analyzed through thematic content analysis, which unfolded into three distinct stages: pre-analysis; material exploration and treatment of the results obtained; and interpretation. ${ }^{11}$ As a result, this led to the construction of thematic categories that originated from the data, representative of the phenomenon analyzed, with an approach towards the theoretical framework of Work Psychodynamics.

Aiming to maintain the study confidentiality, participants were named W, short for "worker", plus a number, following the order of participation in the FG, resulting in the codes W1, W2, W3, W4 and so on. This study was in accordance with Resolution 466/12 of the National Health Council and it was approved by the local Research Ethics Committee, with a Certificado de Apresentação para Apreciação Ética (CAAE - Certificate of Submission for Ethical Appreciation) number 11366112.5.0000.5346.

\section{RESULTS AND DISCUSSION}

Among the 20 nursing workers who participated in the present study, 14 belonged to the hospitalization ward and six to the outpatient clinic. The majority of them were women $(n=$ $19)$ and nurses $(n=12)$ and they had children $(n=13)$. The age group ranged from 26 to 56 years. Their length of time working in the nursing service varied from five to 30 years, while in pediatric oncology, it was between one and 18 years. The majority of them had a postgraduate level of education $(n=18)$ with a daytime shift $(n=14)$ and without other employment relationships $(n=16)$.

Next, the thematic categories that emerged during the analysis will be shown, including the defensive strategies.

\section{Individual defensive strategies used in the pediatric oncology service}

Findings from this study enabled the identification of individual defensive strategies used by nursing in pediatric oncology when dealing with suffering in the workplace. As an example, some workers attempt to separate work from personal life as a defensive strategy, aiming to prevent the suffering caused by issues resulting from such work.
[...] I used to bring them home, but not anymore [workrelated problems], now I leave this place and I forget about them. Still, there are times when something from work comes to mind. [...] I've already suffered a lot because I used to bring all this home. But I managed to learn, change and leave the problems at the hospital. (W1/FG3)

I think we get used, so we're not shaken by anything, not that I'm cold, but here's one thing, out there's another thing [...] You have to know how to separate things, so I separate them really well. (W19/FG4)

It should be emphasized that the need for going on a leave was also evidenced in a study with nursing workers who cared for children with advanced oncological diseases. In this study, participants reported that separating their professional life from their personal life was necessary, aiming to prevent that patient care influenced their lives out of the oncological hospital unit. ${ }^{12,13}$ This shows that the use of such defensive strategy can be common in other contexts.

According to Work Psychodynamics, the attempt to separate the space inside from that outside of the workplace fails because the way one's mind functions cannot be split. As a result, workers cannot ignore their mental load at a certain moment during the day. Thus, they need support from their relationships to maintain their defenses active. ${ }^{5}$

The need for escape and work leaves was also reported in workers' speech, associated with their desire for vacations or at least medical certificates, as these were recognized as alternatives to suffering.

[...] At moments of great stress we think about vacation and free time. A moment when we can't keep our heads straight.(W9/FG3)

I also thought about getting a doctor's certificate and going on vacation. [...] Because I needed to get out of there [workplace] as that environment was making me so anguished. [...] I wanted to run away from that situation. (W3/FG3)

According to Work Psychodynamics, escaping from or avoiding situations or spaces that cause suffering represent a strategy often required for workers' own protection. At times, when it is not possible to momentarily escape from suffering, work performance and the subjective relationship between individual and work can be harmed. ${ }^{14}$

However, at the same time, workers recognize the temporary nature of such strategy. Thus, individuals have become aware of the fact that this strategy only alleviates suffering temporarily, requiring the search for other more efficient and lasting means: 


\begin{abstract}
[...] I can't face things like this, I need to stop thinking about vacation. In fact, I need to plan better to make my routine more productive and lighter, otherwise I'll only think about Fridays. And then Fridays, Saturdays and Sundays are shorter. [...] If a weekday is going to be stressful, I have to make it less stressful, otherwise my life won't go well. So, the key is not to think about vacation or Friday evening only, but about having a nice week. This only depends on me. (W9/FG3)
\end{abstract}

According to Work Psychodynamics, workers' possibilities of transformation and management of work organization are essential for them to find meaning in their job. However, when freedom has been limited and all defensive resources have been used, mainly creating frustration, repetition and impotence and resulting in a level of suffering that can cause mental illnesses. ${ }^{5}$ Thus, workers understand that the desire to run away from work, expressed as the need for vacation, doctor's certificates or weekends, is restricted by the need to redefine suffering.

Regarding children's death, workers perceive it as the end of suffering, which helps them to better accept this moment and their loss, or even the end of their experience with parents' and family members' pain. Therefore, to think about death as a synonym of the end of suffering, as a relief for patients, is a defensive strategy used to help them to accept this situation.

I think like this: their suffering is over, poor them! Enough suffering! [...]. (W18/FG4)

It's strange to say that we get used, but I think that's it, I think we get used to it. (W16/FG4)

It should be emphasized that the meaning of death as a synonym of reduction in pain for patients, their family and nursing is pointed out in the literature. A qualitative study performed with nurses working in oncology showed that, according to them, the death of a patient was seen as the end of suffering, a belief emphasized by the stress that workers experience when palliative care is not able to provide comfort and relief from pain. ${ }^{15}$

Another defensive strategy used by workers is their attempt of not being attached to children to avoid suffering at the time of death. This is because, in their view, the stronger the bond with the child and family, the more they will feel the loss and grieve.

I don't know if I'm too cold, but this [death] doesn't affect me anymore. This would affect me a lot because I used to get attached to the children, but I learned that I can't do this [...]. So, if we don't get very attached to the children, we suffer, suffer with the parents at the moment, but then it goes away. [...] (W14/FG4)
[...] Sometimes I'm a little closed off. [...] I think that this is my way to protect myself. I couldn't do it in any other way. [...] (W2/FG1)

My defense is sulking, [...] it's to always be closed off. [...] In my life, I'm like this, my defense is to be closed off. (W16/FG4)

According to Work Psychodynamics, through defense mechanisms, workers attempt to perform actions to control the context of work causing suffering. These actions can be characterized by excessive control, which represents a reduction in anxiety, fear and insecurity, even including denial of suffering itself or the others, when one cannot deal with them subjectively. ${ }^{16}$

When experiencing the pain and death of others, nurses sometimes seek to deny or avoid reflecting on suffering. This works as an outlet that aims to protect workers' psychological system. ${ }^{17}$ Thus, the decision to avoid emotional closeness towards others in the workplace can be an attempt to have some control over the element causing suffering, which consisted in the emotional relationships with sick children and their family in the present study.

During the observations made, these approaches towards child and family care were not identified among workers participating in the FG. There were bonds of trust and affection between workers and children/family members. Thus, it could be inferred that such strategy is used casually, during moments of conflict or suffering.

As intense emotional relationships are formed between nursing workers and children with cancer and their family, these workers are exposed to work-related losses when children die, when the treatment does not achieve the expected result, or even when children conclude their treatment successfully. Thus, nursing workers often experience the pain of loss that families have to cope with throughout a disease process or at its end. ${ }^{9}$ Thus, it should be emphasized that the perception of care provision itself as a limited activity in the fight for children's life and well-being can be frustrating.

A study performed with Iranian nursing workers performing in pediatric oncology showed routine attempts to repress and mask feelings, especially in cases when family members were not fully aware of their child's diagnosis. Thus, in cases when the disease led to death, workers' attempt to erase the memory of children was the main defensive strategy. ${ }^{2}$

The bond that the nursing team forms with patients is sometimes pointed out as negative by workers, as they become involved and emphasize with patients and family members, thus affecting their life. As a result, as a reaction to difficult situations, the majority of workers keep their distance from patients not to become involved. ${ }^{18}$ 
However, not all workers attempt to escape from suffering. Some reported openly talking to family members about work, aiming to express their anguish, share their experiences and speak about situations that cause suffering.

I talk about everything with her [daughter]. [...] I take good and bad things and we share a lot. [...] She sometimes helps me to overcome a situation that makes me feel anguish and shows me a different perspective [...] (W5) FG3)

I get it off my chest with him [husband] and then I forget about [...] the patients, what happened in here. I don't talk about this at home, but when it's a problem that involves me, I need to get it off my chest [...] (W17/FG4)

These data are in disagreement with a study that showed that pediatric oncology nurses die not reveal their work problems to family members aiming to protect them, as they considered this specialty to be sad and depressing. ${ }^{9}$ In this sense, according to Work Psychodynamics, the family environment can be used to help their members to cope with the adversities of work situations, ${ }^{5}$ a support network for workers who are suffering.

Apart from the process of avoiding the critical points of their work routine, workers seek to rationalize frustrating events. To achieve this, they take refuge in the idea that the care provided is of high quality and this becomes a defensive strategy against the routine frustrations of work.

[...] I try to remind myself that everyone did what they could for that child to get well, for that child to at least feel a bit better, and I think this is what we must take into consideration [...]. I think that we, professionals, must think that we did what we could, we managed to do our best not only for the moment of death itself, but all that came beforehand. [...] More to make you feel relieved and ready to get up the next morning and come to work again [...]. (W11/FG2)

I think I'm learning how to separate things. [...] I know I'm competent, that I'm good at what I do, I don't go back home with doubts about this. I put my head on the pillow and feel at peace, I do what I can and I won't suffer for what I can't do.[...]. (W5/FG3)

According to Work Psychodynamics, $r$ ationalization fulfills the role of strengthening a compensatory thought about situations that are present, facilitating workers' process of acceptance and naturalization. The aim of this defensive strategy is to mask the existing suffering, enabling individuals to have a feeling of order and normality, although experiencing a process of psychological suffering. ${ }^{4}$
Reports also revealed that rationalization was seen by nurses as a strategy to deal with routine work in oncology. ${ }^{13} \mathrm{~A}$ similar finding was observed in a study performed with nurses working in pediatric oncology, according to whom the concern about doing "all that can be done" for a patient and their family enabled workers to feel at peace. However, when health care actions were inefficient to alleviate children's pain and suffering, workers experienced feelings of guilt and helplessness. ${ }^{9}$ Consequently, one can assume that relying on the possibilities of care can be ineffective in certain cases when the disease is overly aggressive.

Additionally, aiming to alleviate the suffering caused by work issues, participants sought leisure activities, valuing pleasurable moments that bring well-being and help them to relieve tensions and routine problems. Moreover, spiritual support was found to be a strategy to cope with suffering in the workplace.

[...] I think we must always indulge in pleasurable activities. I always find the time to have my nails done every week, I set up a time and do it. I always find the time to have a Reiki session once a week. And I always find the time to receive a massage twice a week. [...] We must care for ourselves [...] (W8/FG1)

We got to do other things, not only focus on the hospital [...] I try to go to the gym three times a week, there's loud music there, I go on an exercise bike and feel light afterwards, I burn some calories and my head is lighter [...] (W5/FG3)

We need this spiritual strength, because we come to the hospital and feel drained afterwards. It's at this moment that you can raise your spirit, soothe your soul to go on and clear your thoughts [...] (W3/FG3)

The search for religious support was expressed as a defensive strategy in nurses' speech while experiencing the death and dying process, when belief, faith and prayer appeared as a way to cope with the difficulties that cause suffering in the work routine. ${ }^{17}$ Moreover, the spiritual search was reported as a strategy to minimize suffering and psycho-emotional shocks generated in nurses' care routine for individuals with cancer in an oncology hospital. ${ }^{13}$

Work Psychodynamics emphasizes the use of time outside the workplace as a way to compensate and counterbalance its harmful effects. However, one should be aware that work situations offer few chances for individuals to be fulfilled, i.e. to achieve satisfaction inherent in their task. Thus, work becomes a tedious task, a meaningless way to make money. Work and leisure are on opposing sides. The need to find pleasurable activities out of the work environment shows that something is failing in the work routine. ${ }^{4}$

The fact that the excessive use of defensive strategies can lead workers to a process of alienation stands out in the present 
study. In an attempt to keep their distance from, rationalize or disregard suffering, workers rarely find ways to transform their reality. Thus, there is continuous discouragement and resignation towards a situation that creates suffering. ${ }^{16}$

\section{The group who takes action: the use of collective defensive strategies}

In addition to escaping from suffering, workers also reported collective defensive strategies and actions taken on a regular basis to cope with suffering in the workplace. Coming together as a work group was the defensive strategy most frequently used to resist suffering at work.

In the workplace, talking to my colleagues, I think sharing this with them is the only thing that can reduce my suffering. It's to be able to rely on my colleagues, to know that I'll be able to share things with them and always receive warm words, comforting words.[...] (W1/FG3)

I think that we survive because of the team union, which I think is what keeps us strong. [...] We can alleviate a bit of the daily tension in a conversation with our colleagues. [...] (W1/FG2)

I think I try to reduce this suffering with "group therapy", something we do here to talk about our problems, to help and hug each other, to cry. [...] (W3/FG3)

According to Work Psychodynamics, although individual and group defense mechanisms coexist, the defensive strategies used by workers are mainly collective. This is due to the fact that they are strengthened by the group in the work routine, enabling its continuation. Additionally, suffering is rarely experienced by a single individual, but rather by a group. Thus, this group constructs solutions together, aiming to deal with such situations. ${ }^{16}$

The importance of help and cooperation among work colleagues stands out, when they can vent their feelings, talk and attempt to create a more informal environment. ${ }^{18} \mathrm{~A}$ qualitative study performed with American nurses who worked in pediatric oncology showed that the development of emotional bonds among colleagues helped them to bring meaning to their work and to form support networks during times of anguish. According to participants, the feeling of belonging to the group meant that these nurses had a work center capable of providing support and empathy. ${ }^{9}$

Thus, being aware of the benefits of such strategy and for not mentioning formal spaces for discussion, workers sought to promote meetings with colleagues, creating adequate spaces such as meal times:

[...] Sometimes, we arrange to arrive early to drink tea. For $m e$, it's not difficult to come earlier to have this moment with my colleagues, when we can talk, chill out and feel good. [...] We often bake a cake in the evening for our colleagues, because this makes us feel good. (W1/FG3)

[...] we have moments when we hang out somewhere, when we have dinner, talk and laugh a lot, so much that we don't even see time pass... We need this! [...] (W3/ FG2)

It should be emphasized that, according to what was found in a study with nursing workers, apart from individual strategies, workers also used group strategies, such as team meetings and get-togethers, aiming to alleviate tensions in the work environment. ${ }^{19}$ Thus, the promotion of interrelationships between team members is a group defensive strategy, as good interpersonal relationship stands out. Through such relationship, bonds of friendship and trust are formed, helping to reduce tensions and enabling mutual support, which can facilitate and promote dialogue, in addition to encouraging individuals to achieve their potential. ${ }^{20}$

It should be emphasized that the strategy of "talking" was clearly noted during the observations made in the field, in both sectors. In particular, the snack room and the nursing clinic were identified as true "refuges" for these workers, as these are places where they can talk about several topics and "escape" from problems found in their work routine, even if just for a short time.

Finally, nursing workers reported that experiencing children's death and suffering forces them to rethink their personal life and value their family relationships. In this sense, the redefinition of painful experiences in the workplace also represents a defensive strategy that helps workers find new meaning in what they experience. This finding was evidenced in the speech of the majority of workers and it was recognized by them as a common action, thus characterizing another group defensive strategy.

[...] What influences me at home is to take advantage of every moment I have, to be able to lie down on the floor where the kids play, or to go with them to a square, laugh and get dirty in the sand, [...] and not to get attached to material things [...]. At moment like this, when a child or adult dies, I rethink my life, somehow there is something that will change inside me. At that moment, I'll change my perspective of life. (W3/FG2)

I think we become more dedicated, more careful with our children, we really see things in a different way. [...] We value life more, we experience each day, we share and talk, instead of being worried about silly things [...]. I think this is something that hemato-oncology teaches us. (W13/FG2)

Today I feel satisfied for working in oncology because it's a school for life, a learning process, a spiritual lesson, because you reflect on your life, each moment that you 
work is always a reflection on things, on what matters. [...] When you see a sick person, you see that you're well and that you need to be well to help others, that your problem is small compared to theirs. (W20/FG4)

A study showed that, despite the emotional damage caused to nurses working in pediatric oncology, they understood that their work enabled their perspective of the world and life to change. The work in pediatric oncology can allow workers to have a new view of disease and death. Moreover, sharing their life with children who suffer and die, apart from the families who lose their loved ones, causes workers to feel the need to appreciate the moments of union and joy with their own family. ${ }^{9}$ Thus, this strategy is found to occur not only in the group from the present study, but also in other nursing teams that work in pediatric oncology, in other contexts.

Finally, it should be emphasized that workers perceive the need for specialized support that allows them to have spaces to speak. Therefore, participants themselves recognized the importance of group strategies to tackle work challenges, represented by the verbalization and sharing among workers.

I think that we should have psychological support, moments to discuss, to sit down and talk about our frustrations and fears, even what some death meant to me and how it touched me. Because we're human beings and we have all those feelings that come from our personal history, from our home, and that we take from here to there. We don't have a moment to share, to cry together and to hug. Then, we take this in and try to digest as we can, so I even hide my feelings [...]. (W3/FG2)

This idea is also expressed in a study with nursing workers who cared for children with cancer. They reported that, just like children and their families, the ideal situation would be if workers received psychological support, as they needed to be prepared and emotionally strong to work. ${ }^{12}$

It should be emphasized that suffering in the workplace, apart from the discomfort it causes, can be what triggers workers to seek a way to fight as a group, aiming to change work. To achieve this, spaces for discussion, participation, cooperation and solidarity should be available for workers. These spaces can strengthen the belief in the transformation of suffering into pleasure, through the preparation of powerful strategies. ${ }^{16}$ Thus, the empowering of nursing workers can be an implication, especially among those performing in pediatric oncology.

\section{FINAL CONSIDERATIONS}

From the data revealed by nursing workers, we could understand that their defensive strategies in pediatric oncology, such as conformity, distancing from the experience with children, rationalization and taking refuge in pleasurable moments.
Moreover, group strategies developed by the group were identified. Speaking and listening, coming together as a work group, redefining suffering and the search for a new meaning for life can be understood as efficient group actions, through which nursing workers give meaning to what cannot be changed.

With this approach, possible study contributions for teaching, research, extension and nursing care were evidenced. In terms of teaching, the qualification of these workers should be the focus, especially regarding oncology, aiming to make them well prepared and confident when entering this area. This can minimize suffering and help them to cope with the death found in their work routine. In the present study, this theme should be further analyzed, due to its importance for workers' health. In extension and health care, specific spaces for speaking and listening should be taken into consideration, so they can reflect on and share their experiences of pleasure and suffering in the workplace, apart from recognizing defensive strategies and strengthening resistance actions.

Finally, one of the limitations of the present study was the fact that it was performed in one context exclusively, i.e. in a public university hospital. Consequently, we propose it should be expanded to other realities, such as private institutions in other regions, aiming to further this theme. Furthermore, the present study had a descriptive nature. Thus, it is suggested that future studies should use participatory research, capable of promoting reflection and transformation of reality.

\section{REFERENCES}

1. Guimarães TM, Silva LF, Santo FHE, Moraes JRMM. Palliative care in pediatric oncology in nursing students' perception. Esc Anna Nery [Internet]. 2016; [cited 2016 Dec 7]; 20(2):261-7. Available from: http:// www.scielo.br/pdf/ean/v20n2/en_1414-8145-ean-20-02-0261.pdf

2. Borhani F, Abbaszadeh A, Mohsenpour M, Asadi N. Lived experiences of pediatric oncology nurses in Iran. Iran J Nurs Midwifery Res [Internet]. 2013 Sep; [cited 2016 Dec 7]; 18(5):349-54. Available from: https://www. ncbi.nlm.nih.gov/pmc/articles/PMC3877455/?report=reader

3. Pereira DMB, Bertoldi K, Roese A. Percepções dos profissionais de enfermagem na assistência a crianças portadoras de câncer. Rev Enferm UFSM [Internet]. 2015 Jan/Mar; [cited 2016 Dec 7]; 5(1):112-20. Available from: https://periodicos.ufsm.br/reufsm/article/view/13426/pdf

4. Dejours C. A Loucura do Trabalho: Estudo de Psicopatologia do Trabalho. 6를. São Paulo: Cortez; 2015.

5. Dejours C, Abdoucheli E, Jayet C. Psicodinâmica do Trabalho: Contribuições da Escola Dejouriana à Análise da Relação Prazer, Sofrimento e Trabalho. 1aㅡ. ed. São Paulo: Atlas; 2011.

6. Shoji S, Souza NVDO, Farias SNP, Vieira MLC, Progianti JM. Proposals for improving working conditions at an outpatient clinic: the nursing standpoint. Esc Anna Nery [Internet]. 2016 Apr/Jun; [cited 2016 Dec 7]; 20(2):303-9. Available from: http://www.scielo.br/pdf/ean/v20n2/ en_1414-8145-ean-20-02-0303.pdf

7. Marques FRB, Ferreira MCV, Duarte AM, Balieiro MMFG, Mandetta MA Nature and source of conflicts of relationships in the context of pediatric oncology: an integrative literature review. Cienc Cuid Saude [Internet] 2015 Apr/Jun; [cited 2017 Mai 18]; 14(2):1184-93. Available from: http:// eduem.uem.br/ojs/index.php/CiencCuidSaude/article/view/25247/ pdf_354

8. Jacobs AC, Lourens M. Emotional challenges faced by nurses when taking care of children in a private hospital in South Africa. Afr J Nurs Midwifery. 2016;18(2):196-210. 
9. Conte TM. The lived experience of work-related loss and grief among pediatric oncology nurses. J Hosp Palliat Nurs [Internet]. 2014; [cited 2016 Dec 7]; 16(1):40-6. Available from: http://www.medscape.com/ viewarticle/819582

10. Aschidamini IM, Saupe R. Grupo focal - estratégia metodológica qualitativa: um ensaio teórico. Cogitare Enferm [Internet]. 2004; [cited 2017 Feb 3]; 9(1):9-14. Available from: http://revistas.ufpr.br/cogitare/ article/view/1700/1408

11. Minayo MCS. O desafio do conhecimento: pesquisa qualitativa em saúde. 14ª ed. São Paulo: Hucitec; 2014.

12. Mutti CF, Padoin SMM, Paula CC. Espacialidade do ser-profissionalde-enfermagem no mundo do cuidado à criança que tem câncer. Esc Anna Nery [Internet]. 2012 Jul/Sep; [cited 2016 Nov 15]; 16(3):493-9. Available from: http://www.scielo.br/pdf/ean/v16n3/10.pdf

13. Salimena AMO, Teixeira SR, Amorim TV, Paiva ACPC, Melo MCSC. Estratégias de enfrentamento usadas por enfermeiros ao cuidar de pacientes oncológicos. Rev Enferm UFSM [Internet]. 2013 Jan/Apr; [cited 2016 Nov 15]; 3(1):8-16. Available from: https://periodicos.ufsm. $\mathrm{br} /$ reufsm/article/view/6638/pdf

14. Mendes AM, org. Psicodinâmica do trabalho: teoria, método $e$ pesquisas. São Paulo: Casa do Psicólogo; 2007.

15. Salimena AMO, Teixeira SR, Amorim TV, Paiva ACPC, Melo MCSC. O vivido dos enfermeiros no cuidado ao paciente oncológico. Cogitare Enferm [Internet]. 2013 Jan/Mar; [cited 2016 Nov 16]; 18(1):142-7. Available from: http://revistas.ufpr.br/cogitare/article/view/31320/20027
16. Mendes AM, Costa VP, Barros PCR. Estratégias de enfrentamento do sofrimento psíquico no trabalho bancário. Estud Pesqui Psicol [Internet]. 2003; [cited 2016 Nov 16]; 3(1):1-11. Available from: http://www.e-publicacoes.uerj.br/index.php/revispsi/article/ view/7778/5626

17. Santos JL, Corral-Mulato S, Villela Bueno SM, Cruz Robazzi MLC. Feelings of nurses faced with death: pleasure and suffering from the perspective of psychodynamics of Dejours. Invest Educ Enferm [Internet].2016; [cited 2017 May 18]; 34(3):511-7. Available from: http:// www.redalyc. org/articulo.oa?id=105247786009

18. Moreira AO, Sousa HA, Ribeiro JA. Vivências e estratégias defensivas dos enfermeiros frente ao cuidado em unidade de terapia intensiva. Rev Enferm UFSM [Internet]. 2013 Jan/Apr [cited 2016 Nov 16]; 3(1):102-11. Available from: https://periodicos.ufsm.br/reufsm/article/ view/7207/pdf

19. Kessler AI, Krug SBF. Do prazer ao sofrimento no trabalho da enfermagem: o discurso dos trabalhadores. Rev Gaúcha Enferm [Internet]. 2012 Mar; [cited 2016 Nov 17]; 33(1):49-55. Available from: http://www.scielo.br/pdf/rgenf/v33n1/a07v33n1.pdf

20. Martins JT, Robazzi MLCC. Estratégias defensivas utilizadas por enfermeiros de unidade de terapia intensiva: reflexão na ótica dejouriana. Ciênc Cuid Saúde [Internet]. 2012 Jan/Mar; [cited 2016 Nov 15]; 11(Supl):47-53. Available from: http://periodicos.uem.br/ojs/ index.php/CiencCuidSaude/article/view/5071 